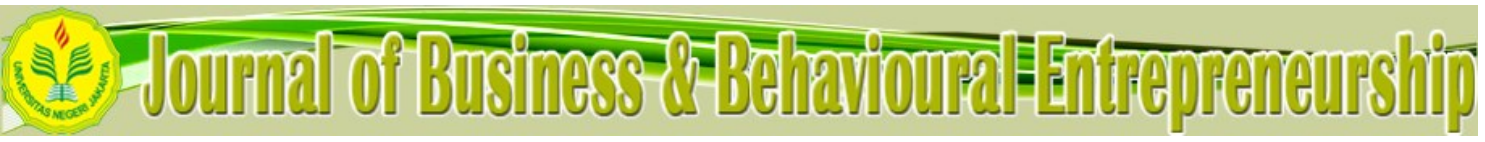

\title{
The Effect of Entrepreneurship Education on Entrepreneurship In- tention of Students of Private Islamic Universities in Jakarta
}

\author{
Bambang Eko Samiono \\ Doctoral Student of Human Resource Management, State University of Jakarta \\ Email: bambangeko_im07s3@mahasiswa.unj.ac.id
}

Ma'ruf Akbar

Pascasarjana, State University of Jakarta

Email: makrufakbar@unj.ac.id

Hamidah

Pascasarjana, State University of Jakarta

Email: hamidah@unj.ac.id

\begin{abstract}
This study aims to analyze the effect of Entrepreneurship Education on Entrepreneurship Intention of students of private Islamic universities in Jakarta. This study shall be focused on the variables of entrepreneurial education, namely Attitude and Self Efficacy, to mediate the effect of entrepreneurship education on entrepreneurial intention. The object of the study was 400 students from private Islamic universities in Jakarta with accreditation $A$ and B, entrepreneurial curriculum as faculty and university subjects, and entrepreneurial concentration in major. This study applied a multivariate analysis using Structural Equation Modeling (SEM) method. The findings suggest that Entrepreneurship Education does not have a positive direct effect on Entrepreneurial Intention, yet has a considerable effect on Entrepreneurial Self-Efficacy and Attitude. However, Entrepreneurial Self-Efficacy has no effect on entrepreneurial intention. Entrepreneurship Intention is influenced by Entrepreneurship Attitude. Furthermore, this study obtained a noteworthy finding, namely the effect of Entrepreneurial Self-Efficacy on Entrepreneurship Attitude.
\end{abstract}

\section{Keywords: Self-Efficacy, Entrepreneurship Intention, Entrepreneurship Education, Entrepreneurship Attitude.}

Received: 15 May 2019;

Accepted: 21 May 2019;

Publish; December 2018

\section{How to Cite:}

Samiono, B., Akbar, M., \& Hamidah, H.. (2018). The Effect of Entrepreneurship Education on Entrepreneurship Intention of Students of Private Islamic Universities in Jakarta. Journal of Business and Behavioural Entrepreneurship, 2(2), 94-102. https:// doi.org/10.21009/JOBBE.002.2.05 


\section{INTRODUCTION}

Entrepreneurship is a program intensified by the government of Indonesia to overcome the unemployment issue, whose main focus is aimed at Micro, Small and Medium Enterprises (MSMEs). This sector contributes $99 \%$ of the total existing business units, able to increase employment up to $97 \%$ of the total labor. It is a highly vital program considering that the number of entrepreneurs in Indonesia is below $1 \%$ of the total population. This figure indicates that Indonesia is lagging behind Malaysia and Singapore whose number of entrepreneurs reaches $3 \%$ and $7.2 \%$ respectively. In addition, the quality and competence of entrepreneurship in Indonesia regionally and globally is lagging far behind. According to the 2018 Global Entrepreneur Index data, Indonesia regionally ranks 7 th out of 10 countries in Southeast Asia. Globally, Indonesia ranks 90th among 137 countries surveyed.

There are 450 private Islamic colleges in Indonesia managed by the Private Islamic Higher Education Cooperation Agency (BKS-PTIS). Higher Education Database (PDDIKTI) reveals 52 universities under the supervision of Higher Education Service Institutions (LL Dikti) Region III, among which are seven Islamic universities, and five of which are private Islamic universities registered with Accreditation A and B. There are merely two private Islamic universities that have special attention to entrepreneurship by opening a special concentration of entrepreneurship. The issues regarding the development of entrepreneurship in private Islamic tertiary institutions have become interesting to study, due to not merely the large number of universities and students in them, but also the fact that Indonesia is the largest Muslim country in the world unable to develop muslimpreneur.

A number of studies have been carried out as approaches to identify various aspects of the problems related to the effect of Entrepreneurship Education on Entrepreneurial Intention in Indonesia and several third world countries, specifically in universities. Studies of entrepreneurial intention were conducted in several universities in Indonesia, for instance by Adnyana and Purnami (2016: p. 60) studying the effect of Entrepreneurship Education on entrepreneurial intensity of students of Udayana University as well as Wibowo and Pramudana (2016, p. 87) examining Entrepreneurship intention of Extension students of Economics and Business Faculty of Udayana University, Bali. Both studies discovered similar findings. Studies of entrepreneurial intention carried out in foreign universities are comparatively diverse. A study was carried out in ASEAN countries by Rengiah and Sentosa (2014, p. 68), examining the entrepreneurial intention of final level students having studied entrepreneurship courses from four universities. A similar study was conducted by Küttim et al (2014, p. 658) on students from 17 European countries. Oyugi (2015, p. 31) examined entrepreneurial intention of students studying entrepreneurship in their third year from three universities in Uganda. Several aforementioned studies have similarities in applying the variables of Theory of Planned Behavior (TPB), using a cross-sectional study and the variables of entrepreneurship education to measure entrepreneurial intention. The findings disclosed that entrepreneurial intention was influenced by entrepreneurship education, entrepreneurial attitudes and self-efficacy.

This research was conducted to study entrepreneurial intentions on the basis of the theory used was Theory of Planned Behavior (TPB) with the assumption that TPB clearly distinguishes attitudes related to personal interests regarding entrepreneurial behavior (personal level), and attitudes due to social influence (social level). This 
study will focus on entrepreneurial education variable and their influence on entrepreneurial intentions. Attitude and Self Efficacy as individual perceptions are used to mediate the influence of entrepreneurship education on entrepreneurial intentions. Attitude and self-efficacy variables is an important indicator in measuring competencies and perceptions.

\section{Objective}

This study seeks to examine entrepreneurial intention of students of private Islamic universities in Jakarta on the basis of Ajzen's Theory of Planned Behavior (TPB) with the assumption that TPB clearly distinguishes attitudes related to personal interests regarding entrepreneurial behavior (personal level), and attitudes due to social influence (social levelThe study shall be focused on analyzing the effect of entrepreneurship education, specifically referring to the perceptions of students in curriculum, teaching methods and the support provided by universities for entrepreneurship towards entrepreneurial intention. Attitude and Self-Efficacy as individual perceptions are the variables selected to mediate the effect of entrepreneurship education on entrepreneurial intention.

\section{THE METHOD OF THE STUDY}

This study applied the method of self-administered survey and associative causal quantitative approach, observing the direct and indirect effects of independent variables on the dependent variable. The Structural Equation Modeling (SEM) method was selected in the analysis of the study. The variables measured in this study were the endogenous variable: Entrepreneurial Intention/EI (Z) by Lee (2012, p.5) and exogenous variable: Entrepreneurship Education/EE (X) by Rengiah and Sentosa (2014,p.53), and intermediate variables: Entrepreneurship Attitude/ATE (Y1) developed by Robison (1991, p.2), and Entrepreneurial Self-Efficacy/ESE (Y2) by McGee (2009, p.965). A Multivariate Analysis with Structural Equation Modeling (SEM) method is used with 1-5 Linkert Scale. The object of the study was students of private Islamic universities in Jakarta under the guidance of LL Dikti III with accreditation A and B as well as entrepreneurial curriculum and concentration in their major. These private Islamic universities are Muhammadiyah University of Prof. Dr. Hamka (Uhamka) and Al-Azhar University of Indonesia (UAI). The sample of this study was determined to be 400 active students having attended entrepreneurship lectures as the faculty and university subjects.

\section{RESULT AND DISCUSSION}

Based on SEM analysis, after obtaining exogenous and endogenous variables that have been fit with the empirical data in the measurement model and analysis of the Overall Structural Model, a combination of all latent variables is obtained. The path diagram of the equation to be estimated is presented in the following figure: 1 .

* The Effect of Entrepreneurship Education on Entrepreneurship Intention of Students of Private Islamic Universities in Jakarta.

* $\quad$ https://doi.org/10.21009/JOBBE.002.2.05 


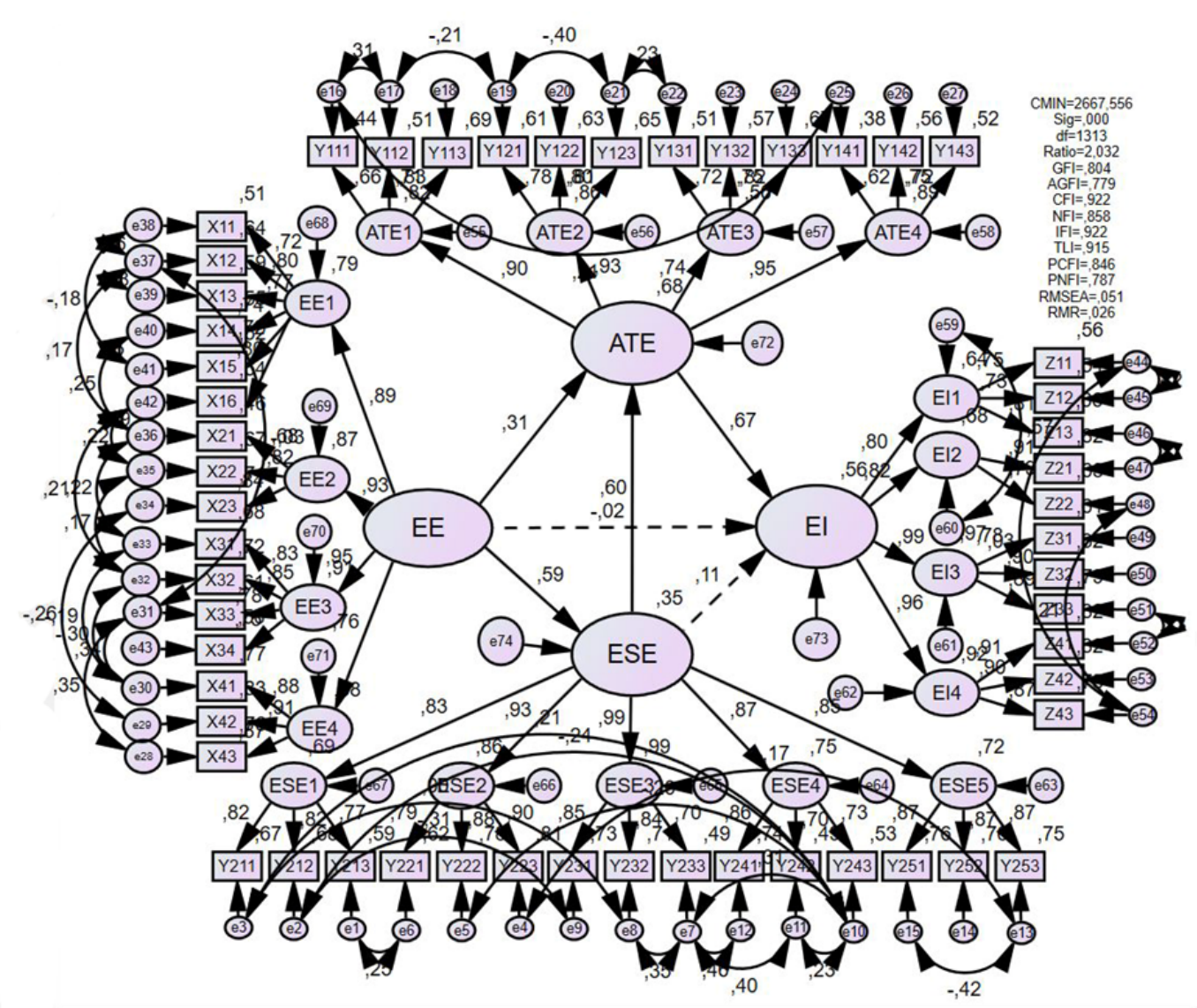

Figure 1: Overall Structural Model fit

The data of the study have obtained a modification of the index to meet the goodness of fit, the results of which are presented in Table 1. This model reveals the "minimum was achieved" result (Chi-square $=2667.556)$, Degrees of freedom $=1313$ and Probability level $=0.000$. Despite zero probability, this result shows that the overall model is in accordance with the sample data. The results of the goodness of fit full model of this study are presented in the following figure.

Table 1: GOF Full Model

\begin{tabular}{|l|c|c|c|}
\hline \multicolumn{1}{|c|}{ Goodness Of Fit Full Model } & Result & & Note \\
\hline Absolute fit Model \\
\begin{tabular}{|l|c|c|c|}
\hline $\begin{array}{l}\text { Root Mean Square Error of Approximation } \\
\text { (RMSEA) }\end{array}$ & 0.051 & $\leq 0.08$ & Good of Fit \\
\hline Goodness of Fit Index (GFI) & 0.804 & $\geq 0.90$ & Marginal Good \\
\hline Incremental Fit Model & 0.922 & $\geq 0.90$ & Good of Fit \\
\hline Comparative Fit Index (CFI) & 0.858 & $\geq 0.90$ & Marginal Good \\
\hline Normed Fit Index (NFI) & 0.922 & $\geq 0.90$ & Good of Fit \\
\hline Incremental Fit Index (IFI) & \\
\hline Parsimonious Fit Model & 0.779 & $\geq 0.90$ & not Good \\
\hline Adjusted Goodness of Fit Index (AGFI)
\end{tabular}
\end{tabular}

The Effect of Entrepreneurship Education on Entrepreneurship Intention of Students of Private Islamic Universities in Jakarta.

* $\quad$ https://doi.org/10.21009/JOBBE.002.2.05 
The results of the model fit test in table 1 show the measurement of the absolute fit model, in which RMSEA $=0.051$ and GFI $=0.804$. Thus, it indicates that the model has good category. The calculation of incremental compatibility model reveals that $\mathrm{CFI}=0.922, \mathrm{NFI}=0.858$ and $\mathrm{IFI}=0.922$, meaning that the model has good criteria Meanwhile, the measurement of the parsimonious fit model shows AGFI of 0.779, implying that the model has good category. Overall, it is stated that the analysis of the goodness of fit full model has been fit. Mostly, test parameters have been fulfilled according to the empirical data. In this study, it is concluded that the structural analysis of the model is possible. To test the magnitude of the influence of constructs, constructs on dimensions, and dimensions of the indicator, the standardized Regression Weight is applied as follows.

Table 2: Standardized Regression Weight

\begin{tabular}{lllr}
\hline & & & \multicolumn{1}{r}{ Estimate } \\
\hline ESE & $<---$ & EE & $\mathbf{0 . 5 8 9}$ \\
\hline ATE & $<---$ & EE & $\mathbf{0 . 3 1 2}$ \\
\hline ATE & $<---$ & ESE & $\mathbf{0 . 6 0 1}$ \\
\hline EI & $<---$ & ATE & $\mathbf{0 . 6 7}$ \\
\hline EI & $<---$ & ESE & $\mathbf{0 . 1 1 3}$ \\
\hline EI & $<---$ & EE & $\mathbf{- 0 . 0 2 4}$ \\
\hline ATE1 & $<---$ & ATE & 0.905 \\
\hline ATE 4 & $<---$ & ATE & 0.946 \\
\hline ATE 3 & $<---$ & ATE & 0.745 \\
\hline ATE 2 & $<---$ & ATE & 0.925 \\
\hline ESE1 & $<---$ & ESE & 0.828 \\
\hline ESE2 & $<---$ & ESE & 0.928 \\
\hline ESE3 & $<---$ & ESE & 0.994 \\
\hline ESE4 & $<---$ & ESE & 0.868 \\
\hline
\end{tabular}

\begin{tabular}{lllr}
\hline & & & Estimate \\
\hline ESE1 & $<---$ & ESE & 0.828 \\
\hline ESE2 & $<---$ & ESE & 0.928 \\
\hline ESE3 & $<---$ & ESE & 0.994 \\
\hline ESE4 & $<---$ & ESE & 0.868 \\
\hline ESE5 & $<---$ & ESE & 0.849 \\
\hline EI1 & $<---$ & EI & 0.799 \\
\hline EI 4 & $<---$ & EI & 0.957 \\
\hline EI 3 & $<---$ & EI & 0.986 \\
\hline EI 2 & $<---$ & EI & 0.825 \\
\hline EE 1 & $<---$ & EE & 0.89 \\
\hline EE 2 & $<---$ & EE & 0.933 \\
\hline EE 3 & $<---$ & EE & 0.954 \\
\hline EE 4 & $<---$ & EE & 0.76 \\
\hline & & &
\end{tabular}

Based on Figure 3, it is concluded that the correlation between constructs is particularly good, specifically more than 0.50 of the following three variables: namely the correlation between entrepreneurship education and entrepreneurial self-efficacy, entrepreneurial self-efficacy and entrepreneurial attitude, and entrepreneurial attitude and intention. Meanwhile, the remaining variables are below 0.50. According to the estimate from the aforementioned table, sub structural and structural regression modeling is arranged as follows:

\section{Sub Structural Equations:}

Entrepreneurial Self Efficacy $(Y 2)=0.589 *$ Entrepreneurship Education +0.21

Entrepreneurship Attitude (Y1) $\quad=0.601 *$ Entrepreneurial Self-Efficacy +0.589

* Entrepreneurship Education +0.08

\section{Structural Equations:}

Entrepreneurship Intention (X)

$=0.670 *$ Entrepreneurship Attitude $+0.113 *$ Entrepreneurial Self-Efficacy $+(-0.024) *$ Entrepreneurship Education +0.08

The evaluation of the effect of exogenous variables on endogenous variables is presented in the Table 3. 
Table 3: Squared Multiple Correlations

\begin{tabular}{|l|r|}
\hline & \multicolumn{2}{|c|}{ Estimate } \\
\hline ESE & \\
\hline ATE & 0.347 \\
\hline IE & 0.68 \\
\hline
\end{tabular}

It is evident that Entrepreneurial Self-Efficacy is explained by Entrepreneurship education by 0.375 or $37.5 \%$, Entrepreneurship Attitude is explained by Entrepreneurial Self-Efficacy and Entrepreneurship Education by 0.68 or $68 \%$ and Entrepreneurship Intention is explained by Entrepreneurship Attitude, Entrepreneurial Self-efficacy, and Entrepreneurship Education by 0.558 or $55.8 \%$.

In terms of the analysis, it is concluded that entrepreneurship education has no effect on Entrepreneurial Intention (-0,024 attitude subscales). This result evidently contradicts several previous studies including those conducted by Lee Wei, (2012, p. 15); Hamidi (2008, p. 304); Oyugi (2011, p. 31); Muofhe (2011, p. 1); Karali (2013, p. 48); Küttim (2014, p. 658) and Malebana (2017, p. 1). However, this study has the similar findings to the study by Bae (2014, p. 217) and Patricia (2016, p. 72), that entrepreneurship education has no effect on entrepreneurial intention.

Further analyzing this phenomenon reveals that the highest positive response of Entrepreneurship Education is entrepreneurial support activities (EE3) of 0.954, primarily in the indicator of the entrepreneurship competition held by the campus (X.3.2) of 0.846. Meanwhile, the lack of focus is discovered precisely in the support provided by the university (EE4) (0.76), particularly the entrepreneurial facilities available on campus (X.4.1) (0.876) as well as the support provided by outside partners for entrepreneurship development on campus (X.4.3). It implies that students of private Islamic universities in Jakarta recognize entrepreneurial support activities (EE2) in entrepreneurship education as highly crucial, in particular various activities in the form of competitions, allowing them to test a business concept into a real business as the results of their education, for instance, student creativity programs or other entrepreneurial competitions. On the other hand, the students notice the lack of support of the universities for entrepreneurial activities (EE4), particularly in the form of entrepreneurial support facilities such as entrepreneurship labs and business incubators as well as in establishing partnerships with outside parties. However, it appears that entrepreneurship education has so far not been able to directly influence entrepreneurial intention of the students.

The findings of this study indicate the reality of the issue in developing entrepreneurial education, including the inability of the culture of education in Indonesia to support the development of entrepreneurial spirit of their students, as highlighted by Ferbiyanto (2013, p. 43). Similar expression is conveyed by Wibowo and Pramudana (2011, p. 67), that entrepreneurship education in Indonesia is inadequate. Furthermore, the success of education process and its output is the benchmark for the success of entrepreneurship education in Indonesia. Entrepreneurship education is able to take place effectively should it is supported by a number of aspects, whether internal or external aspects in the university. The internal aspects are further emphasized on the need for designing an effective learning curriculum able to be delivered through an appropriate teaching method. Complete facilities, both physical and non-physical, to support the course of the education process is also a demand to be fulfilled by universities (Suci et al, 2015, p. 1). 
This study discovered an interesting finding where entrepreneurial self-efficacy has a considerable effect on entrepreneurship attitude (0.601). Evidently, self-efficacy has no effect on Entrepreneurship Intention (0.113). A significant effect of Entrepreneurial Self-Efficacy on Entrepreneurship Attitude is identified when the data analysis is conducted on the Amos program, hence the need for further study and discussion. The applied Theory of Planned Behavior (TPB) reveals no correlation, thus the hypothesis and assumption is not discussed beforehand. This phenomenon is identified in several studies by Saptono (2018, p.50), Matinez (2011, p.14), Izquirdo (2011, p.75), that attitudes mediate the correlation between entrepreneurial self-efficacy and intention.

The analysis of this issue ascertains that the self-efficacy of students is rather high for the ability to manage a business (ESE3) (0.994), primarily in opening a new business (Y2.3.1) (0.855). They tend to be risk-taking (0.828). The ability to overcome risk (ESE1) is mainly to rise from failure (Y2.1.3) (0.769). It implies that Entrtepreneurial Self-Efficacy of students of private Islamic tertiary education in Jakarta is sufficient to manage new businesses as a result of Entrepreneurship Education on campus. However, they are constrained in terms of self-efficacy involving failure to deal with business risks. Certainly, they have not been able to deal with risk, specifically to be able to rise from failure in business. It is a reason why the effect of self-efficacy is not obtained on their Entrepreneurial Intention.

In terms of entrepreneurship attitude, the respondents have high positive attitude of innovation in business (ATE2) (0.946), particularly the attitude to support innovation in a business (Y1.2.3) (0.806). The study found the lack in perceived personal control of business results (SK3) (0.745), mainly related to optimism to control a business venture (Y1.3.1) (0.718). It implies that students of private Islamic tertiary institutions in Jakarta have an attitude of supporting innovation in a business, yet they appear to have personal control, mainly on the results of a business. Apparently, learning about the uncertainties of the results of a business contributes negatively to their attitude concerning Entrepreneurship.

Therefore, it is obvious that Entrepreneurial Self-Efficacy of the students of private Islamic universities in Jakarta, particularly in managing business, has a considerable effect on their Entrepreneurship Attitude in being positive and optimistic in perceiving business as innovation. Nevertheless, their low ability to overcome business failure due to a variety of risks renders them more pessimistic concerning the results of their effort. This effect is rather substantial on Entrepreneurship Attitude rather than on Entrepreneurial Intention. It is concluded that a positive entrepreneurial attitude is the key for students of Islamic universities in Jakarta to be able to increase their entrepreneurial intentions. The entrepreneurial intentions shall not necessarily increase. The essence is for the efficacy to increase. However, entrepreneurial attitude is necessary as an intermediary.

The role of entrepreneurship education is highly important to improve and develop supportive entrepreneurship attitude since positive Entrepreneurship Attitude shall be a mediation affecting Entrepreneurship Intention of students of private Islamic universities in Jakarta. It is possible to develop positive entrepreneurship attitude by adopting them in the curriculum and teaching methods and practicing them in entrepreneurial support activities, one of which is by including motivational materials regarding the entrepreneurial mindset where Islam strongly encourages entrepreneurship exemplified by Prophet Muhammad S.A.W. in his daily life. 


\section{CONCLUSION}

It is concluded that entrepreneurial intention of the students of private Islamic tertiary institutions in Jakarta is strongly influenced by entrepreneurial attitude they have instead of Entrepreneurship Education or Entrepreneurial self-efficacy. Entrepreneurship Education and Entrepreneurial Self-Efficiency are important variables in the formation of Entrepreneurship Attitude. Eventually, it is essential for private Islamic University to have a special curriculum or teaching method able to improve the Entrepreneurship Attitude and Intention. They need to focus on several improvements aspects which are weaknesses in building entrepreneurial intentions. Such as lack of business model material, theoretical exposures and teaching method that are less desirable, and lack of supporting facilities. Universities must be able to change the curriculum not only emphasizing the improvement of hard skills purpose but also soft skills to build motivation, partnership, creativity and innovation aspects. In The end, not only student's self-efficiency will increase but also their attitude.

\section{BIBLIOGRAPHY}

Adnyana, I. G. L. A., \& Purnami, N. M. (2016). Pengaruh pendidikan kewirausahaan, self efficacy dan locus of control pada niat berwirausaha. E-Jurnal Manajemen Unud, 5(2), 1160-1188.

Ajzen, I. (2001). Consumer attitude and behavior. Annals of Tourism Research (Vol. 28). https:// doi.org/10.1016/S0160-7383(00)00072-4

Bandura, A. (1986). The social foundations of thought and action. Englewood Cliffs, NJ: Prentice-Hall.

Bae, T. J., Qian, S., Miao, C., \& Fiet, J. O. (2014). The relationship between entrepreneurship education and entrepreneurial intentions: A meta-analytic review. Entrepreneurship: Theory and Practice, 38(2), 217-254. https://doi.org/10.1111/etap.12095

Brice, Jr. J, \& Spencer, B. (2007). Entrepreneurial profiling: A decision policy analysis of the influence of entrepreneurial self-efficacy on entrepreneurial intent. Academy of Entrepreneurship Journal, 13(2), 47-67.

Febriyanto. (2013). Peran mata kuliah kewirausahaan terhadap minat mahasiswa berwirausaha. Derivatif Jurnal Manajemen, 7(2), 43-48. ISSN: 1978-6573

Hamidi, D. Y., Wennberg, K., \& Berglund, H. (2008). Creativity in entrepreneurship education. Journal of Small Business and Enterprise Development, 15(2), 304-320. https:// doi.org/10.1108/14626000810871691

Izquierdo, E., \& Buelens, M. (2011). Competing models of entrepreneurial intentions: the influence of entrepreneurial self-efficacy and attitudes. International Journal of Entrepreneurship and Small Business, 13(1), 75. https://doi.org/10.1504/IJESB.2011.040417

Karali, S. (2013). Erasmus University of Rotterdam Erasmus Centre for Entrepreneurship the Impact of entrepreneurship education programs on entrepreneurial intentions: An application of the theory of planned behavior (Master Thesis). Co-reader: Hendrik Halbe MSc Erasmus Cent. Erasmus School of Economics Rotterdam.

Küttim, M., Kallaste, M., Venesaar, U., \& Kiis, A. (2014). Entrepreneurship education at university level and students' entrepreneurial intentions. Procedia - Social and Behavioral Sciences, 110, 658-668. https://doi.org/10.1016/j.sbspro.2013.12.910

Lee, W. N., Lim, B. P., Lim, L. Y., Ng, H. S., \& Wong, J. L. (2012). Entrepreneurial intention: a study among students of higher learning institution. Entrepreneurial Intention: A Study Among Students of Higher Learning Institution, (August), 15.

Liñán, F. (2004). Intention-based models of entrepreneurship education. Piccola Impresa/Small Business, 3(1), 1-30. https://doi.org/10.1371/journal.pone.0007418

Liñán, F., Rodríguez-Cohard, J. C., \& Rueda-Cantuche, J. M. (2011). Factors affecting entrepreneurial intention levels: A role for education. International Entrepreneurship and Management Journal, 7(2), 195-218. https://doi.org/10.1007/s11365-010-0154-Z

Malebana, M. J., \& Swanepoel, E. (2014). The relationship between exposure to entrepreneurship education and entrepreneurial. Southern African Business Review, 18(1), 1-26.

* The Effect of Entrepreneurship Education on Entrepreneurship Intention of Students of Private Islamic Universities in Jakarta.

* $\quad$ https://doi.org/10.21009/JOBBE.002.2.05 
Martinez Campo, J. L. (2011). Analysis of the influence of self-efficacy on entrepreneurial intentions. Prospect, 9(2), 14-21. Retrieved from http://dialnet.unirioja.es/descarga/articulo/4208261.pdf

Mcgee, J. E., Peterson, M., Mueller, S. L., \& Sequeira, J. M. (2009). Entrepreneurial self-efficacy: Refining the measure. Entrepreneurship: Theory and Practice, 33(4), 965-988. https:// doi.org/10.1111/j.1540-6520.2009.00304.x

Muofhe, N. J., \& Du Toit, W. F. (2011). Entrepreneurial education's and entrepreneurial role models' influence on career choice. SA Journal of Human Resource Management, 9(1), 1-15. https:// doi.org/10.4102/sajhrm.v9i1.345

Oyugi, J. L. (2015). The mediating effect of self-efficacy on the relationship between entrepreneurship education and entrepreneurial intentions of university students. Journal of Entrepreneurship Management and Innovation, 11(2), 31-56. https://doi.org/10.7341/20151122

Patricia, \& Silangen, C. (2017). The effect of entrepreneurship education on entrepreneurial intention: An experimental study on undergraduate business students. Journal of Management Research, 9(3), 72. https://doi.org/10.5296/jmr.v9i3.11282

Rengiah, D. P., \& Sentosa, P. D. I. (2014). A conceptual development of entrepreneurship education and entrepreneurial intentions among Malaysian university students. IOSR Journal of Business and Management, 16(11), 68-74. https://doi.org/10.9790/487X-161126874

Rengiah, P. (2013). Effectiveness of entrepreneurship education in developing entrepreneurial intentions among Malaysian university students. Southern Cross University, 5(4), 53-61. https:// doi.org/10.11648/j.edu.20160504.13

Robinson, P. B., Stimpson, D. V., Huefner, J. C., \& Hunt, H. K. (2018). An attitude approach to the prediction of entrepreneurship. Entrepreneurship Theory and Practice, 15(4), 13-32. https:// doi.org/10.1177/104225879101500405

Saptono, A. (2018). Do Learning Environment and Self-Efficacy Impact on Student'S Entrepreneurial Attitude? International Journal of Entrepreneurship, 22(4), 1939-4675.

Suci, A., Suroto, B., \& Kuning, U. L. (2015). Model Efektif Pendidikan Kewirausahaan Di Perguruan Tinggi : Perspektif Di, 1-16.

Turker, D., \& Selcuk, S. S. (2009). Which factors affect entrepreneurial intention of university students? Journal of European Industrial Training, 33(2), 142-159. https:// doi.org/10.1108/03090590910939049

Wibowo, S., \& Satria Pramudana, K. A. (2016). Pengaruh Pendidikan Kewirausahaan Terhadap Intensi Berwirausaha Yang Dimediasi Oleh Sikap Berwirausaha. Manajemen, 5(12), 8167-8198.

* The Effect of Entrepreneurship Education on Entrepreneurship Intention of Students of Private Islamic Universities in Jakarta.

* $\quad$ https://doi.org/10.21009/JOBBE.002.2.05 